\title{
ISTRIJANSKI REGERE FINES: TRADICIJSKA KULTURA I BALKAN U DISKURZIVNOJ KONSTRUKCIJI IDENTITETA
}

\author{
Dr. sc. Sandi Blagonić \\ Hrvatska akademija znanosti i umjetnosti \\ Zavod za povijesne i društvene znanosti u Rijeci, \\ Područna jedinica u Puli \\ Prolaz kod kazališta 2, HR - 52100 Pula \\ sandiblagonic@hazu.hr
}

UDK 323.1(497.5-3Istra) Izvorni znanstveni članak Primljeno: 5. 9. 2016. Prihvaćeno: 16. 11. 2016. DOI: http://doi.org/10.21857/mwo1vc57ny

U tekstu se analizira diskurs o tradicijskoj kulturi i Europi, odnosno Balkanu na regionalnom političkom tržištu. Interpretacija tradicijske kulture Istre sklapna je s političkim potrebama aktera, pa se u tu sorhu ona rabi kako bi naglasila identitetsku različitost Istre spram ostalog dijela Hrvatske. U regionalističkom diskursu Istra i politika IDS-a interpretirane su kao pripadajuće Europi i europskim vrijednostima, dok se nacionalističkom diskursu pripisuje balkanizam.

Ključne riječi: Balkan; istrijanstvo; Istrijani; Europa; Istarski demokratski sabor; Hrvatska demokratska zajednica; tradicijska kultura.

Konstrukcija identitetskog zajedništva sadrži u sebi refleksiju na prošlo. Ona je usmjerena na proizvodnju kontinuiteta kojim zamišljena zajednica legitimira svoje mjesto u sadašnjosti. Suprotno mijeni običaja tradicionalnih seoskih sredina (donedavno $\mathrm{u}$ etnologiji interpretiranih petrificirajućim etnološkim prezentom kao znanstvenim certifikatom ispravnosti popularnih pogleda na selo predmoderne Europe, kao mjesto nepovijesne, stalno ponavljajuće matrice), izmišljena tradicija uznastoji oko dovođenja u vezu, pa i izjednačavanja sa "starim“, čime se osigurava fiktivna veza s prošlošću u sadašnjosti reproducirana ponavljanjem novih praksi (Hobsbawm, 1993.), što rezultira paradoksom nacionalizma: diskrepancijom između objektivne modernosti fenomena nacije i, za njezine protagoniste, drevne starosti (Wehler, 2005: 49).

Odnos tradicije i izmišljene tradicije moguće je interpretirati u kategorijama folklora i (političkog) folklorizma, gdje folklorizam karakterizira izmještenost fol- 
klora iz njegova tradicijskog okruženja, pri čemu se ostvaruju posve nove funkcije i kreiraju posve nova društvena značenja. Kako primjećuje Christian Giordano, zajedništvo je utoliko čvršće ukoliko je postojalo ranije, čime se osigurava osjećaj trajnosti i nepromjenjivosti zajednice. Gemeinsamkeitsglauben, vjerovanje o posjedovanju zajedničkih odlika, na čemu, kako je tvrdio Weber, počiva kohezija zajednice, ima jasno usmjerenje u prošlosti (Giordano, 2001: 76). Stoga je povijest, u povezanosti s Gemeinsamkeitsglauben zajednice, u stanju stalnog preispitivanja i prilagođavanja zahtjevima sadašnjosti, pa je, zbog njezina, po sadašnjost zajednice, utilitarnog učinka, Giordano naziva ",aktualiziranom poviješću“, ujedno i „situacijskom poviješću“ (isto: 76-77). Aktualiziranje povijesti jest dvostruko: ona se dekonstruira uklanjanjem činjenica, simbola i društvenih vrijednosti koje se povezuje s "mračnim“ ili "degeneriranim“ razdobljem, odnosno reverzibilizira projiciranjem $u$,stanje stvari kakvo je bilo nekad“ (isto: 88). Aktualiziranu povijest moguće je sagledati i kroz diskurs o tradicijskoj kulturi: povijest, kultura i identitet međusobno su povezani fenomeni.

Polje kulture privilegirano je mjesto konstrukcije identiteta, napose u političkim mitovima. Diskurs o kulturi mjesto je na kojem se sklapaju slike izolirane, homogene, samozadovoljne i od drugih ugrožene nacionalne zajednice (Čolović, 2000: 86). Ta se slika distinktivnih kultura, koju stvarnost demantira, dotiče samog nacionalističkog ideala izgrađenog na ideji o harmoničnom poklapanju političkih, etničkih i kulturnih granica.

Prilagođavajuća osobina aktualizirane povijesti što istovremeno stvara ono što Christophe Jeffrelot naziva "oslobađajućom amnezijom“ (usp. Martin 1995: 10) razlikuje ju od drugih, također nužno filtrirajućih pristupa stvarnosti. Primjerice, onkraj znanstvenog prosedea, rekonstruiranja strukturiranog kroz ispuštanje (omission), odabir (selection) i utjecaj (influence) (Slavec, 1988: 123), njegova induktivnog i deduktivnog postupka, politička ideologija koristi se nepravilnom upotrebom tih metoda, dok se suvremeni mediji upravljaju prvenstveno zanimljivošću isječaka stvarnosti (Katunarić, 2003: 188). Sustavi filtriranja u sferi potonjeg teško propuštaju misli, programe, nakane, tumačenja, očekivanja, tekstove ili projekte nasuprot kratkotrajnosti zbivanja (posebno završenih epizoda) i njegove kulturne, političke i prostorne bliskosti, aspekta iznenađenja, konfliktnosti događaja, velikih šteta i uspjeha i dviju razina personifikacije (pojedinačne osobe ili ugledne osobe) kao čimbenika koji povećavaju vrijednost vijesti (Meyer, 2003.). Ipak, znanost je gdjekad, zahvaljujući povlaštenoj poziciji proizvoditelja znanja, posebno uspješno, introjicirala dominantne društvenoideološke terminološke koordinate, napose u popularnoj historiografiji, udžbenicima povijesti i lingvistici, i dodatno ih naturalizirala. ${ }^{1}$ Tako naprimjer

Tako npr. pridjev „okcitanski“ i imenica „Okcitanija“ jesu „,učene i recentne riječi (iskovane latiniziranjem izraza langue d'oc, lingua occitana), s namjenom da označavaju znanstvene realitete koji, bar zasad, postoje jedino na papiru“ (Bourdieu, 1992: 119). Dunja Rihtman Auguštin ukazuje na 
Denis Kuljiš (2008.) u naslovu knjige Mirjane Sanader i suradnika Hrvatska u antici, posprdno, ali točno, vidi potrebu „da se hrvatstvo utemelji u povijesnoj dubini u kojoj više nema tragova postojanja rodnog kolektiviteta, kao neki falsificirani pedigree za mladu, novu pasminu (...) kao da napišeš knjigu Hrvati u svemiru“. Slično tome, skulptura Apoksiomena, što datira iz helenističkog doba, pronađena 1996. u podmorju Velih Orjula, otočića smještenog jugoistočno od otoka Lošinja, u dijelu je hrvatskih stručnih krugova, a onda i u javnosti, nazivana i Hrvatskim Apoksiomenom. Ako u sferama političke mitologije etnonacionalne zajednice mogu i ekspandirati u duboku prošlost, krećući se prema prekoračenju vremena (kao u Hrvoja Šošića: „Hrvatsku je stvorio Bog, dakle ona je oduvijek“,', cit. prema Senjković, 2002: 131), čemu su sakrosanktizirani "oltar domovine“, „,sveta i vječna Hrvatska“, diskretna pomoć, znanstveni diskurs nacionalizira najčešće ondje gdje i jest najdostupniji u naslovima ili nazivima, izvan njegova manje dostupnog, hermetičnog diskursa. Spreman etnizirati sve vrijedno što se na njegovu „etničkom teritoriju“ nađe, njime se reproducira ono što nalazimo u polju političke mitologije koja barata terminima eminentno etnonacionalnog teritorija i vremena proizvodeći Hrvatsku koja je davnija od sebe same, kao paroksizam: "oduvijek“. ${ }^{\prime 3}$

Kićenje sadašnjosti ornamentima starog i izvornog, fenomen o kojem Hermann Bausinger govori u kontekstu političkog folklorizma, primjenjiv je i na uporabu simbola. Poput naoko apolitičnih manifestacija iz sfere folklorizma, i politički "stari“ i „izvorni“ simboli pokazuju sposobnost da se njima i budućnost konstruira kao puka projekcija neke izgubljene povijesti (usp. Bausinger, 2002: 174). O tome je

kongruenciju političkoideološkog i etnološkog diskursa u socijalizmu, gdje je bilo „uputnije za naša kulturna dobra da imaju protoslavensko ili starobalkansko porijeklo, kvalitetu koja ih može razlikovati od kulturnih značajki hegemonijske urbane civilizacije. Unutar ovakva vrednovanja, romanski ili njemački kulturni elementi uvijek su se uzimali negativnijima od starobalkanskih, pogotovo slavenskih elemenata. Elementi iz drevnih civilizacija bili su cijenjeniji od utjecaja suvremenih civilizacija." (Rihtman-Auguštin, 1988: 13)

2 Slične su sljedeće izjave: „Predlažem hrvatskim povjesničarima da počnu govoriti kako Hrvati ovdje žive od pamtivijeka. Samo ako priznamo da smo tu od pamtivijeka, onda nam se povijest $\mathrm{Hr}-$ vata produbljuje barem do Hallstatske kulture i još dublje. U tom smo slučaju mi baštinici i širitelji izvornoga kršćanstva, a ne nekakvi barbari." (Dragan Hazler, cit. prema Dežulović i Lucić , 1999: 278), „Ne vjerujem da smo kao spasitelji Bizanta od Avara došli početkom sedmog stoljeća samo u krševitu Hrvatsku. Logično mi je da smo još prije, možda čak i puno prije, recimo prije 1995 godina, doselili u ravničarsku Panoniju, možda i odmah nakon što je presušilo Panonsko more. (Marko Matić, cit.prema isto), „Hrvati i Srbi su dvije najstarije civilizacije na ovom području." (Franjo Tuđman, cit. prema isto).

3 S druge strane, pravila medijskog filtriranja i prerađivanja gdjekad čine slično kao kad su navlastitom interpretacijom znanstvenih nalaza svojevremeno etnizirali gene tvrdeći kako su „hrvatski (...) geni stari 27.000 godina" (cit. prema Blagonić, 2007: 121) stvarajući, govorom ranije usporedbe, „Hrvate na Jupiteru“. Uz to, aktivnost povijesne rekonstrukcije, iako neovisna o društvenom pamćenju, poticaje može dobiti od pamćenja društvenih grupa, ali mu ih može i dati (Connerton, 2002: 25), slično kao što etnografski tekstovi što tematiziraju određene lokalitete sudjeluju u petrificiranju aksiomatskog viđenja društvenog svijeta definiranog diskontinuitetnim i oštrim kulturnim razlikama umjesto bešavne mreže kulturnih varijacija (Jenkins, 2001: 23). 
riječ pri proizvodnji „hrvatskoga“, od devedesetih naovamo, kad se iz širokog diskurzivnog skladišta poseže za tkanicama trobojnica na tradicijskoj nošnji (relativno novim izumom ranije konstrukcije nacionalnog), gdjekad viđenih subverzivnima u socijalističkom razdoblju, izvornim hrvatskom grbom ili novogovorom. Sve su to elementi jedne projekcije, arkadizirane fantazije o prošlosti koja se, nakon devetstoljetnog intermezza, na početku novog, etničkog zlatnog doba ima obnoviti. Istu projektivnu funkciju unutar političkih mitologija može imati mitologizirani lik vođe, ovdje Franje Tuđmana, koji se (poput tkanice ili grba) „prostire u povijesti i prošlosti“ (Milan Ivkošić, cit. prema Dežulović i Lucić, 1998: 327). Kroz njega, kao utjelovljenja ličnosti nacionalizirane povijesti kojom se odvija navlastita „epifanija predaka“ (Čolović, 2000: 22), Hrvati mogu „osjetiti svu borbenost Šubića, Zrinskih, stalne borbe Tvrtka, heroja Hrvoja Hrvatinića i svih kasnijih velikana što su za Hrvatsku učinili - Starčevića, Radića, Mačeka i Pavelića!“ (Anto Baković, cit. prema Dežulović i Lucić, 1999: 321). Na sličan način, na jednom fašističkom plakatu, „Cezar je zaživio u Duceu". Transcendirajući granice vremena i prostora, kao simboličko tijelo istovremeno vremenite i nevremenite "vječne Hrvatske", „pojedinac Tuđman nije više pojedinac Tuđman nego hrvatska sudbina. U tom izrazu zajedništva postalo je jasno da Tuđman nije donosio odluke sam, nego su ih donosili povijest $\mathrm{i}$ narod u Tuđmanu." (Milan Ivkošić; cit. prema isto, 325). Osim stabilizirajuće uloge u razdobljima krize, kad aktualizacija uloge vođe ima okupljajući potencijal, članovi se zamišljene zajednice mogu osjećati povezani ljubavlju prema vođi (Bielfeld, 1998: 167). Osjećati-se-s-vođom-kao-jedno oslonac je bespomoćnoj masovnoj individui zbog njezina odgoja, dijagnosticira Wilhelm Reich u analizi nacionalističke samosvijesti u Njemačkoj dvadesetih i tridesetih godina 20. stoljeća (2014: 71). Ta se ideja nalazi i u stihovima dječje pjesme iz socijalističkog razdoblja: „Tito, Tito, to smo svi mi / I mama, i tata, i ja i ti“", kao i u onome što u nacističkoj Njemačkoj uočava Robert d'Harcourt: „Hitlerova omladina - to je takoreći pleonazam“.

Simboli kojima se stječe glasnogovorništvo identiteta dio su ulaganja u konstrukciju specifičnih, legitimizirajućih govorenja o prošlosti koja je svojevrsni „diskurs skrojen po mjeri“ (Hobsbawm, 1983: 14), sastavljen u skladu s ukusima i potrebama aktera simboličkih natjecanja. Hobsbawm (isto, 12-14) povijest, osim nacionalnih simbola, nacionalizma i ostalih s nacijom povezanih fenomena, sagledava kao dio socijalnog inženjerstva. Pritom su simboli i monumenti ekspresija jedne takve retroverzije:

Pred očima živih, povijest bi bez svoga monumentalnog izraza bila puka apstrakcija. Društveni prostor je pun spomenika koji nisu neposredno funkcionalni: bilo da je riječ o veličanstvenim kamenim građevinama ili skromnim zemljanim oltarima, svatko može imati hopravdano osjećanje da mu je većina njih prethodila i da će ga nadživjeti. 
Slična se veza s prošlošću postiže repetitivnim kodovima suvremenih političkih rituala poput dizanja zastave ili izvođenja himne. Istovjetnost ritualnih radnji što su se događale, događaju se i što će se, izvjesno je, događati iskaz je kontinuiteta, ali $i$, što je za zajednicu isto tako važno, stabilnosti. Ako se u tradicionalnim ritualima ponavljanje često usmjerava na održavanje cikličnog reda stvari čitavog univerzuma, ovdje je univerzum sveden na sakralizirano tijelo vlastite nacije, ali i, unutar "jezgrene doktrine" nacionalizma, na održavanje našeg svijeta. ${ }^{4}$

Jedan od toposa uvučenih u identitetske diskurse unutar šireg političkog i, uopće, javnog diskursa onaj je o kulturi. Iscrtati granicu znači kreirati, makar i činom povlačenja granice, Drugog, ujedno time, dijelom, definirajući i kolektivno mi. Jedan od privlačnih poligona tog regere fines jest tradicijska kultura. Pritom se ona ne nadaje kao nekakav stalni skup karakteristika koje bi, jednom istaknute, oštro odvajale regiju od regije, etniju od etnije, naciju od nacije. Granice - etničke, regionalne, nacionalne - ma koliko podvrgnute pokušajima naturalizacije, jesu ponajprije konstrukt.

Prije kulture, čak i posve naturalizirana granica Istre, onda i Istrijana, pokazuje mijene kroz 20. stoljeće. Dok je za Liburnjane „tekar preko Učke počinjala Istra a ljudi tamo bili su Istrani“, početkom 20. stoljeća Istra je za „Bujce“ bila „kraj ispod Buja uz more" (Jardas, 1971: 18). Na Proštini ${ }^{5}$, sudeći prema podacima Ante Cilige, Ćići („Kranjci“) nisu bili „Istrijanci“ (Valić , 1944: 11). ${ }^{6} \mathrm{U}$ tom smislu, valja primijetiti i utjecaj republičke, a kasnije i državne granice na sjeveru Istre u 20. stoljeću, kako za nacionalne, tako i za uže identitete, poput regionalnog.

Traženje specifičnog, a zanemarivanje sličnog u kulturi strategija je jačanja identitetske konstrukcije. Pritom se teritorijalne granice političkog interesa trebaju poklapati s kulturnim elementima tog prostora: iz tih se kulturnih elemenata, između ostalog, crpi legitimitet crtanja, odnosno simboličkog povlačenja granica. Ti kulturni elementi potvrda su da su granice posvećenog prostora postojale i prije nego što ih je hegemonijski diskurs uopće obznanio.

Teško je sjetiti se nekog kulturnog elementa koji je hrvatski u smislu svehrvatskog i ekskluzivno hrvatskog. Slično je i s nečim što bi trebalo biti isključivo i ekskluzivno istarsko. Etnolozi, ti nekadašnji sudemiurzi nacija i nacionalnog, sudionici

"Jezgrenu doktrinu" nacionalizma čine truizmi o svijetu podijeljenom na nacije što stoje odvojene zasebnim povijestima i sudbinama; o nacijama što su izvor cjelokupne političke i društvene moći, a lojalnost naciji hijerarhijski je najviša; o poistovjećenju s nacijama kao preduvjetom slobode i samoostvarenja; te slobodi i sigurnosti nacija koje su nužne za svjetski mir i pravdu (Smith , 1998: 119).

5 Toponim Proština potječe iz vremena bizantske vladavine u Istri i nastao je od grčkog Prós Tîmon označavajući tijekom srednjeg vijeka općinsku šumu za ispašu. Kao takav čest je na područu južne Istre (Bertoša, 1972: 26). Proštinom, odnosno Proštinarima nazivaju se stanovnici područja omeđenog Marčanom, Krnicom i Kavranom, što, preciznije, uključuje sela i zaseoke Mutvoran, Cokune, Male i Velike Vareške, Peruške, Joviće, Šegotiće, Pavićine, Išiće, Cveke, te nekoliko stancija (usp. Valić, 1944: 15; Bertoša, 1972: 26).

6 Tone Valić pseudonim je Ante Cilige pod kojim je, kao insider, napisao zbirku novela Štorice iz Proštine kojima tematizira razdoblje kraja 19. stoljeća sve do 40-ih godina 20. stoljeća. 
etnonacionalizacije kulture, ali i, ponekad, sustvaratelji regija danas, u određenom smislu mogu biti fragmentizatori zamišljene unificiranosti - otkrivanjem procesa $\mathrm{u}$ kojem određeni kulturni element dominantna nacionalna perspektiva naziva, na ovome mjestu, ponajprije hrvatskim, dok je on za periferiju istarski. U stvarnosti, on je često uže ili šire rasprostranjenosti ${ }^{7}$, ali lišen korisnosti izvan dominantnih diskursa, osuđen na višestruku preradu i zadobivanje pragmatičnih, naturaliziranih značenja.

Istražujući usmenu književnost, sličan zaključak o nacionalnoj ekskluzivnosti folklornih elemenata donosi Maja Bošković-Stulli:

Ukupnost regionalnih i lokalnih obilježja, uzevši u obzir i dijalekatsku raznolikost, čini raspoznatliiv korpus hrvatske usmene književnosti; no, gotovo nijedna crta nije izolirana i posebno samo hrvatska. Statične nacionalne zatvorenosti u folkloru nema.

(Bošković-Stulli, 2000: 160) ${ }^{8}$,

jednako kao i Jasna Čapo Žmegač (1997: 203), koja običaje uz Uskrs s nekih hrvatskih područja zapaža u diskontinuiranom pojavljivanju širom Europe.

Strategijom izmišljanja i produciranja ekskluzivnosti kulturnih elemenata ili kad u percepciji stanovništva već postoje kao takvi - njihova hipertrofiranja što služi jačanju grupne pripadnosti koristi se Ivan Pauletta tvrdnjom:

Tko bi se htio ozbiljnije pozabaviti Hrvatima u Istri, morat će se potruditi objasniti barem dvije iz niza antropoloških specifičnosti Istre. Prvo - od kuda Istrijanima tako osebujan muzikalni i vokalni melos, odnosno, koji još Hrvati tako sviraju i pjevaju? I drugo - gdje su i koji Hrvati ikad gradili male poljske kućice, većinom okrugle sa čunastim krovom bez ikakvepotpore, u tehnici suhoziđa-kažune?

(Pauletta, 2000: 62)

Kad bi „muzikalni i vokalni melos“ bio parametar omeđivanja regije, tada bi ona, osim Istre, obuhvaćala i Hrvatsko primorje i sjevernojadranske otoke, pa bi se netko zainteresiran za nešto veću regiju, parafrazirajući spomenuto pitanje, mogao upitati: „Odakle stanovnicima nekadašnje Zajednice općina Rijeka tako osebujan muzikalni i vokalni melos, odnosno, koji još Hrvati tako sviraju i pjevaju?“

\footnotetext{
7 Tako naprimjer na području federalne države Donja Austrija, takozvane Kellergassen, staze izvan sela na kojima se nalaze podrumi u kojima se vino preša i čuva, turističkom su komercijalizacijom predstavljene kao tipični simboli Donje Austrije, iako ih se može naći i u Gradišću, Češkoj, Slovačkoj i Mađarskoj (Köstlin, 2004: 165, 166).

8 Svojevrsnu svjetotvornost što proizlazi iz moći imenovanja moguće je vidjeti na predmetima u afričkim kulturama ,... kojima smo mi dali etničke nazive “, iako se sreću „znatno izvan granica unutar kojih su pojedine grupe lokalizirane“ (Augé, 2003: 113).
} 
Izneseno mišljenje o ekskluzivnosti pjevanja i sviranja u Istri dijelom proizlazi iz etnomuzikološke terminologije. Termin „istarska ljestvica“ koji se odnosi na tonske odnose u glazbi ponajprije Istre, Hrvatskog primorja i Kvarnerskih otoka do danas je prevladao u znanstvenoj, a onda i svakodnevnoj upotrebi. Ivan Matetić Ronjgov, najveći pobornik tog termina, i sam je ukazao na njegovu izvanznanstvenu motivaciju:

Bilo kako mu drago, ja sam - obzirom na spomenuti specijalni položaj Istre, koji je uostalom danas aktuelniji, no ikada dosele, pa i faktičkih specijalnosti naše narodne glazbe, ja sam - velju - za to, da toj našoj zemlji ostane bar jedan privilegij, ali bez okova u koje ga je sapeo dr. Žganec, pa da ne pišemo "istarska“, već istarska ljestvica. Ako moji argumenti sa strogo znanstvenog stajališta ponešto i hramlju, nek se uvaži, da ove retke piše glazbenik, koji je u isto doba i istarski - iredentista.

(Matetić Ronjgov, 1925: 37)

Termin „istarska ljestvica“ sugerira endemičnost istarske glazbe. Netočnost u tekstu Ivana Paulette može se objasniti popularnim stavom prema kojem naziv „istarska ljestvica“ sugerira Ono što je ovdje, prateći procese regionalizacije kulture u političkom diskursu, zanimljivije, odnosno tendencioznost selekcioniranja elemenata kulture. Takvim bi pristupom bilo moguće igrati se unedogled pri konstruiranju regija.

Kao i s istarskom ljestvicom, slično je i s pitanjem o Hrvatima i kažunima. Osim što građevine takvih karakteristika znatno prelaze granice Istre, pa i Hrvatske, one, s druge strane, nisu nikakav sveistarski fenomen. Sasvim bi legitimno mogao nastupiti neki budući fragmentizator „,istarskog“, iz južne Istre naprimjer, pa se zapitati: „Gdje su i koji ljudi u Istri gradili kažune?“ Pritom ne treba negirati visoku identifikacijsku razinu kažuna s Istrom: ona je danas zbiljska, iako zamišljena. Tako je na jednom odmorištu dionice Istarskog ipsilona, na tom ne-mjestu kao produktu nadmodernosti što nevidljivim ostavlja povijest, društvene odnose i identitete preeksponirajući istodobno lokalne elemente (Augé, 2003: 97, 124; 2005.), sagrađen sanitarni čvor u obliku kažuna. ${ }^{9}$ Poljska građevina što je služila za sklanjanje od vremenskih nepogoda na polju, spremanje alata te motrenje eventualnih kradljivaca plodova i koja, kao takva, nereflektirana, nije posjedovala veće simboličko značenje, pa je $\mathrm{u}$ fazi modernizacije dugo prepuštena propadanju, folklorizacijom je zadobila novu, prije svega simboličku funkciju. Negativne reakcije dijela javnosti na činjenicu da je „kažun“ postao javni WC samo su pokazale da on, izmješten iz ranijeg konteksta, funkcionira kao vi-

\footnotetext{
Poput kažuna u zapadnoj Francuskoj duž autocesta, benzinske su crpke pokrivene škriljevcem tipičnim za krovove u Bretanji, dok u Provansi nalazimo crepove (Augé, 2003: 124). „Jer obilježje nemjesta je da kod prolaznika stvara predodžbu o lokalnom koja je prezasićena stereotipnim slikama, rasplinuta pod djelovanjem mnoštva ponovljenih prizora uniformiranog planeta“ (isto: 125).
} 
sokovrednovani simbol identiteta. Stoga je i istarski župan Ivan Jakovčič od izvođača BINA Istre zatražio da se „kažuni“ sruše ili prenamijene (M. U., 2003.), što je rezultiralo najavama da će „kažun“ iz, po regionalni identitet desakralizirajućeg, zahoda biti prenamijenjen $\mathrm{u}$ znatno prihvatljiviji turistički info-pult. ${ }^{10}$

Ondje gdje Pauletta naglašava razlike, novinar Nedjeljne Dalmacije, Josip Jović, u reportaži iz Istre vidi samo sličnost:

Ovo čak štoviše, nije slijepo crijevo Hrvatske nego hrvatsko srce. Istra ima i oblik srca. Jezik, toponimi, duh, fizionomije, sve je tu hrvatsko. Sve autentično hrvatsko, hrvatskije od mnogih drugih krajeva.

(Jović, 1993.)

Ukratko, politički diskurs podržava sliku svijeta određenog „diskontinuitetnim i oštrim razlikama“ namjesto „bešavne mreže kulturnih varijacija“ (Jenkins, 2001: 23) (istovremeno, ako je to i koliko jest moguće, diskurzivno homogenizirajući proizvedeni teritorij) baš kao što, primjerice, južnoslavenski dijalekatski areal nije razdijeljen granicama (kako se to klasifikacijom dijalekata $u$ nacionalne dijalekte sugerira) već zbog „,neosjetnog sučeljavanja jednog dijalekta sa susjednim“ prije čini „zone drobljenja dijalekata" (linguistic shatter zones - Custred, 1997: 45) (Bugarski, 2002: 95). Riječ je o mahom preuzetim shvaćanjima konstruiranim u polju znanosti kao što je već spomenuti termin „istarska ljestvica“. Poput petrificirajućeg učinka na aksiomatsko viđenje svijeta omeđenog čvrstim granicama, što ga etnografski tekstovi, tematizirajući određene lokalitete, mogu producirati (Jenkins, 2001: 23), tako je podjela Hrvatske na areale koju je, kao uporište za znanstveni rad, proveo Milovan Gavazzi, imala za posljedicu naglašavanje različitosti te nespominjanje mogućih zajedničkih osobina regija (Köstlin, 2001: 38) ${ }^{11}$. S druge strane, upravo arealne studije

$\overline{10}$ Istrijanizacija identitetskih markera reproducira se i kroz potrošačke prakse koje se sve više razvijaju u 1990-ima u promijenjenim društvenim uvjetima. Tartufi, koji se vežu ponajprije uz Motovunsku šumu i na kojoj selo Livade počinje graditi svoj imidž, postaju od 1990-ih dio onoga što se zove istarskom kuhinjom, iako ranije na poluotoku nisu bili uobičajena namirnica. Tako se i pizza, globalizirano jelo iz druge kulinarske tradicije, tartufima ili istarskim pršutom istrijanizira, pa često nosi upravo naziv „pizza istriana“, baš kao što se u Japanu, spravljanjem hrane s morskim ježom (Bestor, 2006: 145) japanizira, stvarajući neku vrstu glokalnog kulinarstva. Tako konstruirani kulturni identitet, među ostalim i tartufizacijom Istre, velikim dijelom reproduciran u turizmu i kroz svakodnevne prakse, građen je i u političkom diskursu, najuspješnije zahvaljujući IDS-u, stranci što nudi „više od politike“. Već u prvom promidžbenom videospotu koji prati četvoricu muškaraca za igranja briškule, kartaške igre koja otprije predstavlja zavičajni simbolički resurs. Jedan od njih baca ,jaku“ kartu izgovarajući pritom „Karig za Istru“ - „karig“, koji na političkom tržištu ima biti IDS (Orlić, 2004: 37). Sličnu transformaciju simboličkih resursa u političko polje početkom 1990-ih, na temelju procjene dobiti, ostvaruje IDS na predizbornim skupovima na kojima nastupa Franci Blašković i na kojima se, kao i kasnije, kad Franci Blašković postaje veliki kritičar politike IDS-a, nude vino, fritule, kroštule i srdele, ukratko: „regionalni istarski identitet“ (isto). granice među arealima (Rihtman-Auguštin, 1992: 85). 
pokazuju ono što je dokumentirano i u brojnim etnološkim atlasima: da se granice u kojima vrijede određeni kulturni predmeti ili osobitosti tek veoma rijetko podudaraju:

Kada se pragmatično govori o kulturi (o njemačkoj kulturi, Bavarskoj kulturi, kulturi Poljaka koji su se doselili u rursku oblast (...)) uvijek treba imati u vidu da kultura nema čvrste konture, već se sastoji od velikog broja parcijalnih kulura.

(Bausinger, 2002: 315)

Ovdje međutim, za učinke diskursa, nije važna njegova formalna istinitost već značenja koja on za sudionike ima; ono dakle što je izraženo Thomasovim teoremom kako situacija koja biva definirana kao realna jest realna i u svojim posljedicama (usp. Merton, 1995.). Na tom se tragu može razumjeti i uključivanje društvenih protagonista u etnografska pisma (usp. Appadurai, 1992.) kao što, slično tome, novija sociolingvistička istraživanja uvode pristup koji govornu zajednicu (speech community) sagledavaju kao skupinu koju definiraju sami akteri (Hudson, 1990: 33) s obzirom na to da se subjektivne granice među dijalektima često ne podudaraju s onima, uvjetno objektivnim, utvrdivim preko izoglosa (Bugarski, 2002: 105), što analitički uvelike pomaže razumijevanju različitih razina društvene interakcije i identifikacije. Tako se, u Istri, „našost” prepoznaje govorenjem „po istrijanski”, „po domaću”, kriteriju što se opire kategoriziranju pomoću izoglosa:

- Prije kada smo bile na đelatu, si rekla - ovaj čovik je sigurno naš, ki je reka brageše. Ča to znači biti naš?

- Istrijan. Da priča po našu, kako i ja. Oni nas nisu razumili kada su bili uvde oni Slavonci izbjeglice. Nanke svaku petu, jer mi više besid rečemo ki spada pod Talijane, po talijanski mi naprimer dosta stvari ki ja rečen e da e koši, koši je talijanska riječ e, e. I ne znan, jer mi smo se tu bili zgojili pod Italijom, ja san. Italija je bila tu dvajset i pet lit. Od osamnaeste do kvarnar i treće. Je bila, i onda vidiš ti i osnovnu školu talijansku, obavezno san morala završiti talijansku školu $i$ to.

\section{(...)}

- Po čemu ti poznaš da je niki Istrijan?

- Po tem ga poznan, samo po razgovoru, samo kad govori, kad je reka dojdi vamo, mama te zvala da ti digne brageše. Si vidija (smijeh) to je naš čovik, Istrijan tu. Zajno se ga pozna, zajno se ga pozna. Istrijan je taj ki priča po domaću, istrijanski. Ni dijaleto vamo, ni tamo - istrijanski. Mi imamo kone svoji dijalet i gotovo. Mi kušeljamo po našu, mi rečemo kušeljamo, kušeljaš z ovin, kušeljaš z onin ki reče kušelja. Razgovara to, uno... ${ }^{12}$

(Orlić, 2004: 50, 51).

12 Ivona Orlić vodila je, u Musalešu, u svibnju 2003. godine, razgovor sa svojom nonom, Fumom Orlić, rođenom 1928. u selu Dokići. 
Diskurs o granicama unutar političkog polja uvelike preuzima već uspostavljene dominantne mentalne mape.

Istru doživljavamo i opisujemo kao cjelovitu zemljopisnu jedinicu; Istri znanstveno pristupamo kao cjelovitoj zemljopisnoj $i$ povijesnoj jedinici, ali kada je riječ o društvenom, kulturnom $i$ jezičnom ustroju Istre ne možemo ne primijetiti kako je njezina cjelovitost tek metonimijski posljedak preklapanja naše mentalne mape Istre i stvarne zemljopisne i geopolitičke konfiguracije života na poluotoku. Dok mentalna mapa Istre ostvaruje neutralni odnos s jezičnom, kulturnom i etničkom raznolikošću i različitošću, stvarna mapa Istre pronalazi u toj različitosti i raznolikosti svoje legitimacije. Istra ( $p$ )ostaje tako hrvatska, slovenska i talijanska Istra.

(Blagoni, 2006: 469, 470)

\section{Ostracirani Balkan i prigrljena Europa}

Esencijaliziranje kulture unutar polja javnih diskursa etnonacionalizma kojima se konstruiraju nepremostivi kulturni, a onda počesto i "civilizacijski“ i „moralni“ jazovi, što etnonacionalizam, slijedeći vlastiti ideal, u konačnici hoće vidjeti kao poklapanje s političkim granicama nacije strategija je političkih elita kao važnih pregalaca u proizvodnji, odnosno reprodukciji etnonacionalnih identiteta. Projekt nacionalizma podrazumijeva konsenzus o strogim kulturnim granicama. Stoga, paradoksalno, nigdje nije postojalo takvo slaganje i posvemašnja suradnja etnonacionalno sučeljenih elita kao u razdobljima kriza, u zajedničkim radnim akcijama zajaživanja kulturnih granica kojima se konstruiraju opreke „"mi“ $\mathrm{i}$ „,oni“. Jedini njihov spor nastaje oko teritorijalnog prostiranja esencijaliziranih kultura diskurzivno povezanih s uobičajenim legitimacijskim matricama poput tla, predaka i krvi.

Jedna od dominantnih strategija kojima se gradila etnonacionalna divergentnost, ali i, kako će se vidjeti, divergentnost različitih razina lojalnosti, manihejski je diskurs o Balkanu i njemu sučeljenoj Europi. Preuzimajući dominantne zapadnjačke slike Balkana (Todorova, 1998.), Balkan postaje neizostavno mjesto u političkom, uopće identitetskom diskursu na području Hrvatske, odnosno bivše Jugoslavije krajem 20. stoljeća.

Je li protivljenje da se bude sve ono što Balkan dominantno znači istovremeno i pobuna protiv izvanjske, nivelirajuće perspektive slijepe za ikakve nijanse? Je li ta epska jednostavnost kojom dio diskursa na Zapadu eksternalizira ono čemu nema mjesta u sebe-slici istovremeno jednako iskrivljena kao i pokušaji da se unutar geografskog Balkana diskurzivno odrede granice mentalnog Balkana? I jedno i drugo, u pokušajima da negativno konotirani Balkan smjeste onkraj granica vlastitih pripadnosti jest iskrivljeno koliko i ispravno. No, ako se, kako primjećuje Todorova, „Balkan 
može izjednačiti (...) sa svojim otomanskim naslijeđem" (isto: 32), ako se balkanstvo najčešće definira toposima tradicijske i popularne kulture koji nisu mediteranski, alpski ili panonski, ne treba li u odricanju balkanstva u nekom kontekstu vidjeti ne samo kao eksternaliziranje svega onoga što Balkan znači već i kao sredstvo da se, makar i grubo, iskažu neke percipirane identitetske nijanse? Istovremeno, polisemičnost pojma postavlja prilične zapreke koje, da bi se preskočile, trebaju stalni dogovor oko toga što Balkan konkretno znači. Istovremeno proces eksternalizacije zla u diskursu IDS-a istovjetan je onom na Zapadu: granice „monopola na barbarstvo“ (isto: 21) u oba slučaja jesu čvrste i započinju ondje gdje završava situacijski aktualan identitet: $\mathrm{u}$ Istri, $\mathrm{u}$ privatnom jednako kao i u dominantnom političkom govorenju tijekom devedesetih, najčešće „preko Učke“. Dok su u dominantnom popularnom diskursu u Istri granice Balkana teritorijalne, one su u etnonacionalnome prije svega etničke, određene zamišljenom homogenošću, pa tek onda i teritorijalne.

Ipak, oštra granica „etničkih“, odnosno „regionalnih“ kultura koje se u političkom diskursu konstruira istovremeno je međa što dihotomizira moralno od nemoralnog kao dio procesa pretvaranja poznatog u nepoznato i koje, $\mathrm{u}$ krajnjoj konzekvenciji, završava fabriciranjem depersonaliziranog neprijatelja:

Posljednjih godina u političkom govoru u Sloveniji i Hrvatskoj primjetno je bilo nastojanje da se političke ili vojne akcije koje se tamo poduzimaju opravdavaju i legitimiraju kao poduhvati koji su u skladu s vrijednostima i interesima evropske kulture. Navodno je u interesu Evrope, na primjer, da se na tlu bivše Jugoslavije povuče i utvrdi nova granica između njenog zapadnog i njenog istočnog dijela, odnosno, između 'skromne i radne zapadno-katoličke tradicije' $i$ 'violentnog, pokvarenog orijentalno-bizantskog naslijeđa' (cit. prema Prošić-Dvornić, 1995: 295), kako se izrazio slovenski ministar znanosti Petar Tancig lipnja 1991.

(Čolović, 2000: 55)

I kad se balkansko, u širokoj paleti negativnih stereotipa, može prepoznati unutar našeg - etničkog, tada je ono samo neprirodna naslaga jugoslavenskog razdoblja ispod koje se uvijek otkriva primordijalni etnonacionalni identitet diskurzivno koncipiran najčešće kao biće čije se sebstvo temeljno razlikuje od balkanskog. U interpretaciji Nevija Šetića:

Držim kako Hrvatska ne pripada ni po čemu na Balkan, a pogotovo ne po mentalitetu $i$ kulturnom identitetu. No, povezanost $i$ život u prooj i drugoj Jugoslaviji ostavio je traga i određene posljedice koje su najvidljivije u neefikasnom, neodgovornom, neprofesionalnom, netolerantnom i nedostojanstvenom ponašanju pojedinaca kojih ima na soim razinama i bez obzira na stanačku 
pripadnost, $i$ koji vješto manipuliraju i koriste ranije apsolvirano ponašanje u dneonom funkcioniranju, a što doista ne pripada hrvatskoj uljudbi i hrvatskom identitetu. ...Danas se aktualna hrvatska vlast ne može optuživati za balkanski sindrom. Oni koji su vratili dostojanstvo, slobodu, teritorijalnu cjelovitost, samostalnost, međunarodno priznanje i uvažavanje našeg državnog subjektiviteta, jednom riječju hrvatski ponos i suverenitet duboko sam uvjeren da ne žele i ne mogu biti neprecizni, neodgovorni i netolerantni ljudi.

(Šetić, 2003: 94, 95) ${ }^{13}$

Ako su Srbi, naspram Hrvata, u dominantnom nacionalističkom diskursu 1990-ih naprosto Balkanci, takva se retorika nije mogla potpuno konstruirati u odnosu Zagreba i Istre naprosto stoga što Hrvati i Istrijani (ako se uopće dopusti takva, idealnotipska podjela) ne funkcioniraju kao disjunkti već latentni disjunkti. Te su lojalnosti, istarska i hrvatska, najčešć lojalnosti unutar segmentirane hijerarhije višestrukih identiteta dijela građana Istre. Stoga je politički diskurs IDS-a najčešće usmjeren na lociranje političkog „balkanstva“ u vladajućeg HDZ-a koji je „svojim tulumašenjem pokazao još jednom kako izgleda Balkan ${ }^{\prime 14}$, a tek posredno i onih koji slijede integralni nacionalizam.

Sigurno je da u vladajućoj stranci postoje i oni koji bi željeli razrješenje sukoba na balkanski način. No da bi se ostvarilo takvo rješenje potrebno je dvoje.

Ivan Jakovčić (cit. prema Jambor, 1994.)

Iako se može naići na primjere gdje se granica između Istre i Hrvatske kao emanacije prijetećeg Balkana postavlja posve stameno:

Kada smo razgovarali o autonomiji, iskristalizirao se nekoliko težnji. Jedan je da se moramo riješiti Hrvatske da bismo se riješili Balkana. (...) Većina nas se složila da trebamo istaknuti prihvatljivu ideju da se ne rade lomovi u Europi, ali da promoviramo autonomiju onog dijela Istre koji je u Hrvatskoj.

Ivan Pauletta (cit. prema Latinović, 1997.)

Hrvatska se locira na Balkan ili nekamo između njezinih europeiziranih i balkaniziranih elita koje se najbolje snalaze u ambijentu „balkanske krčme“ „u kojoj su sva sjetla ugašena“, a čiji kraj predstavljaju „paljenje svjetla“, „,novi ljudi“ i „,novi dani“ (Ivan Jakovčić, 1995.). Sugestivne metafore Balkana kao područja mraka, du-

\footnotetext{
$\overline{13}$ Citat je dio, do knjige Nevija Šetića, neobjavljenog intervjua što ga je sa Šetićem, u svibnju 1996. godine, vodila Andrea Latinović.

14

Upotreba turcizma dodatno pojačava ekpresiju Balkana: tulum (tur.) - prazna mješina; pren. pijanka, lumperaj, nered (Anić, Goldstein, 1999.).
} 
bine i nepomičnosti stoje naspram istarske ili IDS-ove pokretljivosti prema europskom svjetlu; zvjezdanim visinama kontrapostirane su balkanske dubine do kojih se tonući dolazi. Stoga, „ako IDS popusti, Hrvatska će potonuti u potpuni mrak, a Istra bi u tom slučaju izgubila sve." (cit. prema Žužić, 1997.).

Politikom koju vodi HDZ Hrvatska ostaje duboko na Balkanu, usidrena u balkanske rasplete $i$ balkanski mrak. Istra u tome neće sudjelovati, niti će podržati politiku velike Hrvatske niti velike Srbije, niti politiku konfederacije Hrvatske i BiH. Zato $u$ tom kontekstu zadržavamo pravo da promijenimo stranački program, tj. da se izborimo za sasvim drugačiji status Istre ako nas Tuđmanova politika odvede u nekakvu jadransku, južnoslavensku ili nekakvu inu konfederaciju. Mi balkanski mrak u Istri sigurno nećemo, ovdje će žute europske zoijezdice biti upaljene dan i noć.

(Divković, 1995.)

Sličnom metaforikom koristi se Jakovčić 1996. godine na konferenciji sazvanoj, kako se tvrdi, radi promidžbe i ohrabrivanja drugih regionalnih stranaka iz Hrvatske, kad upozorava kako alternativa Europi jest nekovrsna „Balkanska asocijacija“. Prema Jakovčiću „Istrijani ne žele ostati u mulju balkanske kaljuže“ (cit. prema Ballinger, 2002: 254). Kaljuža, poput mraka, dopušta kretanje koje ostaje neprimijećeno, ali je, više od toga, prepreka kretanju, životnosti, ona je prirodno stanište netransparentnosti, pojma instaliranog tijekom devedesetih, kao prijetnje pravnoj državi. Ona je, napokon, prljavština, sve ono u što se uranja kad se kaže Balkan, sve ono od čega se čisti kad se kaže Europa. Potonji pojam, Europa, odnosno europejstvo, jedan od osnovnih pojmova iz palete IDS-ova diskursa, što se antagonizira balkanstvu, ${ }_{15}^{15}$ problematizira novinarka Anita Malenica pitanjem Neviju Šetiću: „Jesu li grubosti i

15 Opozicijom Europa - Balkan jednako se koriste i IDS i HDZ. No, dok je za IDS odnos prema onome što Europa znači nedvosmislen, hrvatski nacionalistički politički diskurs, ovisno o kontekstu, gaji dvojak odnos prema Europi. Kako primjećuje Boris Buden , Europa jest „ne samo mjesto na kojem smo oduvijek bili, nego i cilj ka kojem se krećemo. Njezina se prisutnost u nas doživljuje jednako snažno kao i njezina odsutnost. Ona je područje najsublimnijih vrijednosti pravde, slobode i jednakosti, ali ujedno i mjesto pervertiranja tih vrijednosti. Ona je jednako predmet našeg obožavanja i žudnje kao i predmet razočaranja i zazora. Kao njezin odabrani narod koji ju spašava čas od njezinih najljućih nepriatelja, čas od nje same, mi smo europskiji od nje, ali i antieuropskiji od nje." (Buden, 1996: 193). Tako don Anto Baković, pregalac hrvatske populacijske politike devedesetih, piše: „Prema tome, kličem: Hvala ti, Bože, što nismo u Europi! Europa nije dostojna nas Hrvata. Europa bi morala doći i moliti na koljenima nas Hrvate da uđemo u Vijeće Europe, kako bismo među njima unijeli malo pameti, poštenja i junaštva,Europa ide svome kraju! Brakovi bez djece, toliki mladi i bez braka, nemoral, seks, kontracepcija... Što će nam takva Europa?!" (cit. prema Dežulović i Lucić, 1999: 78). Slično: „Pa nismo li mi Hrvati tisućama godina stariji od nekakvih primitivaca vez povijesti i bez imena, i ne bi li ti internacionalistički mediokriteti trebali od nas učiti što je civilizacija, kultura, povijest, dostojanstvo, viteštvo i, naravno, Europa. Žele li učiti o Europi i europskom ponašanju, nek izvole doći u Hrvatsku!“ (Velimir Bujanec, cit. prema isto: 127), jer: „Mi smo bili Europa i prije Europe“ (Žarko Domljan, cit. prema isto), „najeuropejski Europejci“ (Mate Ćavar, cit. prema isto). 
psovke, koje su se čule na maratonskoj sjednici Skupštine županije Istarske primjerene ljudima koji se kunu u Europu i 21. stoljeće?"

Nevio Šetić odgovara:

Takvo ponašanje nije primjereno hrvatskom društvu u Istri i Hrvatima Istre koji nisu takvi. Nisu takvi ni Talijani Istre, Rekao bih da se talijanaši tako ponašaju i čelništvo IDS-a koje je palo na ispitu. IDS ne želi nigdje vidjeti hrvatsku politiku jer su oni zarobljenici, još uvijek, federalističke jugoslavenštine i talijanstva. (cit. prema Malenica, 1998.)

Vulgarnost što se, onkraj narativa o „hrvatskoj uljudbi“, obično pripisuje balkanskom ovdje se pripisuje "talijanašima“ i zarobljenicima "federalističke jugoslavenštine“. Jedna vrsta nemoralnosti povezana je s drugom: psovka s "talijanaštvom“ kao oblikom identitetske mimikrije, nemoralnim poricanjem primordijalno shvaćenih identiteta. Naspram toga, nevulgarni, stoje Hrvati i Talijani Istre: verbalnom je purizmu imanentna etnička čistoća.

Vrijednosno konotiranim prostornim dihotomijama zapad - istok te gore - dolje pridodaje se i vremenska: prošlost - budućnost. Prije trećosiječanjskih izbora 2000. godine Dorotea Pešić Bukovac (IDS) poručuje kako je HDZ-u, koliko god se bunio protiv balkanskih asocijacija, upravo tamo, na Balkanu, mjesto, i zato će ga opozicijska šestorka ostaviti u 20. stoljeću (Tomčić, 1999.). Slično lociranje sinkronijske nesinkronije pri kojoj se HDZ situira u prošlost izriče Ivan Jakovčić :

Mislim da je iluzorno stvarati ozračje da Talijani žele Istru ili Dalmaciju, tako razmišlja politika koja Hrvatsku vidi u 17. i 18. stoljeću, a ne u 21. To je problem funkcioniranja naše države.

(cit. prema Lovrić, 1999.)

Reagirajući na skidanje ploče na talijanskom jeziku na zgradi Županije u Pazinu, predsjednik Talijanske unije Giuseppe Rota za Hrvatsku tvrdi da „,neustrašivo čuva svoj izrazito bizantski mentalitet", unatoč nastojanjima da se udalji s Balkana (Rotta, 1998.). Lociranje „balkanskoga“ izvan Istre događa se i kad se ono oslikava, rjeđim, pozitivnim stereotipima. Književnik Drago Orlić, spominjući „vjekovnu negostoljubivost", „zatvorenost", ,"strepnje pred tuđinom“ i ,"nekomunikativnost" stanovnika Istre, piše:

Istranin nije nikad upoznao famoznu balkansku gostoljubivost; kada bi mu netko to ponudio, on bi vjerojatno umro ili propao u zemlju od - srama. Valjda je to poradi povijesne uvjetovanosti $i$ vjekovnog života uz mrgodne i moćnije strance, na vrlo mobilnoj granici, žitkoj poput živog pijeska, kao najisturenijoj enklavi 
i ćeliji slavenstva spram zapada, na tom minijaturnom poluotoku, gdje su vjetrovi povijesti željeli da se tu sastanu i zajedno žive: Romani, Germani, Slaveni.

(...)

Nama krijancija, što će reći uljudba, nalaže odbiti gostoprimstvo. Evo tipičnoga (lažnoga) gostoljubivog poziva i tipičnoga (lažnog) odbijanja:

- Ča ćete pasati poli nas na bićerin?

- Ne, ne! Nan je sila i preša uvi bot. Ćemo ben drugi put, ter si ne ujdemo, ne! Smo naši, ča ni više dani nego kobasic!"

(Orlić, 2005: 235, 236).

Iako se balkanstvo unutar Istre $\mathrm{u}$ javnoj sferi locira ponajprije $\mathrm{u}$ sučeljenim stranačkim pozicijama, posredno u političkom istrijanstvu kojega je IDS glavni proizvoditelj, odnosno, s druge strane, u onome što je deprecijativno obuhvaćao i obuhvaća pojam „,veliki Hrvat“, ona se u Istri najčešće pripisuje onima „preko Učke“. Boraveći u Rovinju, Pamela Ballinger susrela se s mišljenjem kako Balkan počinje na rovinjskom slavoluku, u starom gradu naseljenom imigrantima s istoka koji se, zbog toga, smatra imigrantskim gradom. Rovinjci se stoga šale da se u starom gradu osjećaju kao u Sarajevu ili Mostaru. Pritom, u tvrdnjama svojih istarskih poznanika, detektira uobičajene tvrdnje o „istrijanskosti“, koja znači miroljubivost, radišnost i red suprotstavljen prljavom, ratobornom i nesređenom „,balkanskom“ (Ballinger, 2002: 254).

Ta je drugost prisutna i među neelitnim slojevima:

Evo, ja osobno, mogu ti reći da kad ideš malo tamo naprijed. Rijeka... Rijeku isključujem, ali kad se digneš malo gore, to doživljavam... Ne da doživljavam, nego se osjećam kad da sam došao u neku drugu državu. Nemoj shvatit ništa krivo, nego jednostavno zbog toga jer oni tamo totalno drugačije razmišljaju. Mislim da smo mi puno napredniji u našim razmišljanjima i da smo puno bliži zapadu. Kad dođem tamo, osjećam se kao da sam na Balkanu. To je totalno različito... Mislim, puno primitionije žive, primitivnije razmišljaju... Ne mislim sad nikog vrijeđat s tim, ali mislim da je to tako, to su činjenice, u stvari. Pogotovo, ne znam, Gorski Kotar, Lika, to su jako...primitiono žive. Jer poznam tamo neke ljude i mislim da su to jako različiti načini života i razmišljanja. ${ }^{16}$

(cit. prema Kalapoš, 2002: 123,124)

\footnotetext{
16 Sugovornik Sanje Kalapoš pod pseudonimom Nik, rođen 1970. godine u Pazinu; po zanimanju tehničar, zaposlen kao glazbeni urednik na Radio Pazinu. Razgovor vođen u ljeto 1998. godine.
} 
Slično svjedočenje, percepciju vlastite grupe artikuliranu „od gore“ s nenaznačenim, lebdećim drugim, zabilježila je Sanja Kalapoš u druge sugovornice ${ }^{17}$ :

Sad mi pada slogan IDS-a: "Zemlja dobrih ljudi“. Mislim da su u potrefili onu bit u srcima ljudi, Istrana. Je, zemlja dobrih ljudi. Čini mi se da se nigdje ljudi sa strane ne mogu dobro prihvatiti kao tu. To je ono što krasi Istru, što svi kažu koji ovdje dođu, da su zaista dobri ljudi. Možda to ponekad i nije dobro, jer su možda malo i previše, onako, podilaze svima, ne znaju se pobunit, na znaju se izborit za neka svoja prava, i tako. (...) Sad, možda je malo relativan pojam, što je za nekoga dobro, a što nije. Mentalitet kao takav ima te dobre strane što su ljudi... Ne znam, nisu svadljivi, prilagodljivi su, možda su malo... Sad mi fali izraz, malo previše... Neaktioni, neprobitačni. To je ono što istarskim ljudima fali. Jer nas ima jako malo koji su se probili, koji su nešto postigli u svijetu, ne znam, čak i na razini države. Evo, nema nas ni u Vladi, ako ćemo gledat politiku, uvijek smo nekako na margini, to je taj mentalitet ljudi. Ali s druge strane, mentalitet koji je jako tolerantan.

(cit. prema Kalapoš, 2002: 126)

Slogan „Zemlja dobrih ljudi“ istovremeno podrazumijeva i one značajne Druge, najčešće Hrvate izvan Istre ili, šire, one „preko Učke“ što, ovisno o političkim i inim konjunkturama, zadobivaju stupnjevitu stranost. Slična, latentno relacijska sintagma „brava gente“ upotrijebljena je da označi Talijane kao dobre nasuprot nacistima, lošim Nijemcima, s tom razlikom što je u prvom slučaju teritorij umjesto etničnosti postavljen kao okvir te okupljajuće dobrote..$^{18}$ Tako „Istrijani imaju jednu, rekao bih, genetsku manu - nisu naučili mrziti druge. ${ }^{\prime \prime 19}$ (Damir Kajin, cit. prema Rašeta, 1998.).

Balkanizam je u diskursu IDS-a pragmatično diskurzivno sredstvo (Ashbrook, 2006.). Aktiviran u sučeljavanju s diskursom nacionalne uniformnosti, istovremeno

$\overline{17}$ Sugovornica pod pseudonimom Viktorija, rođena 1964. godine, diplomirala politologiju, zaposlena kao novinarka na Radio Pazinu. Razgovor vođen tijekom ljeta 1998. godine.

Slično tome, negativno viđenje „Valonaca kao profitera" u širokoj upotrebi kod Flamanaca služi istovremeno jačanju pozitivnog identiteta potonjih (Brouillard, 2004: 265).

Osoba, noseći višestruke identitete, može biti, ovisno o situaciji, klasificirana kao x, y i z, pri čemu će joj, kad situacijski biva klasificirana kao x, biti pripisana mirnoća, dok će joj, klasificiranoj kao „Y“, biti pripisana agresivnost. Kad bude klasificirana kao „Z", moguće je da će joj se pripisati nešto treće. Tako ista osoba, društvenom klasifikacijom i korištenjem stereotipa, može biti definirana kao mirna i agresivna, prodorna i povučena, dobra i loša. Konkretno, ponegdje je još i danas, posebno u starijeg stanovništva, u Istri moguće naići na sugovornike koji Vlahe u zapadnoj i južnoj Istri definiraju kao agresivne (slično je i s nekim gradskim stereotipima), dok se istima, kad postaju Istrijani, pripisuju posve drugačije karakteristike (usp. Blagonić, 2008.). 
se, kao i na Zapadu, rabi kao eksternalizacija zla. Pamela Ballinger (2002.) u istrijanstvu, preciznije u njegovoj „,autentičnoj hibridnosti“, vidi moguću indigenu strategiju isključivanja, usmjerenu napose spram imigranata s Balkana:

\begin{abstract}
Uistinu, ako regionalisti postavljaju miješane brakove kao ključ istarske convivenze, to implicitno mora biti evropska (tj. talijanska) vrsta miješanog braka što objašnjava zašto je convivenza uspjela u Istri, za razliku od Bosne (i Jugoslavije općenito), gdje su se miješani brakovi pokazali podjednako učestali.
\end{abstract}

(Ballinger, 2002: 253)

\title{
ZAKLJUČAK
}

Na istarskom političkom tržištu, od 1990-ih dalje, razvidno je postojanje diskurzivnog napora da se elementi tradicijske kulture rabe kako bi se njima impregnirao identitet na koji se regionalistički akteri pozivaju. U tom smislu vidljivo je nastojanje konstrukcije svijeta i identiteta omeđenih oštrim, diskontinuitetnim razlikama (usp. Jenkins, 2001: 23) koje su ujedno i granice moralnog i nemoralnog, reda i nereda, kako se to može vidjeti na diskursu o Europi i Balkanu. Naime, u uvjetima političke pluralnosti, snažnije je, s promjenom društvenog sustava, kako na nacionalnoj, tako i na regionalnoj razini, prisutan diskurs o Balkanu, odnosno njegovoj suprotnosti - Europi. Dok se na nacionalnoj razini binarna opreka Europa - Balkan tijekom devedesetih primjenjivala ponajvećma da bi se, pripisujući joj balkanstvo, stigmatizirala srpska politika i Srbi uopće, IDS istu opreku primjenjuje konstruirajući sebe (zajedno s istrijanstvom) kao autentičnog aktera onoga što se $\mathrm{u}$ javnom diskursu percipira „europskim vrijednostima“ povećavajući time prestiž istrijanskog identiteta kao identitetske osnovice te stranke.

\section{Bibliografija}

Appadurai, Arjun. 1992. Putting hierarcy in its place. Rereading cultural anthropology. George Marcus (ur.). Durham, N. C: Duke University Press, 35-45.

Ashbrook, John. 2006. „Locking Horns in the Istrian Political Arena: Politicized Identity, the Istrian Democratic Assembly, and the Croatian Democratic Alliance“. East European Politics \& Societies, 20/4: 622-658.

(Augé, Marc) Ože, Mark. 2003. Varljivi kraj stoleća. Beograd: XX. vek.

(Augé, Marc) Ože, Mark. 2005. Nemesta. Beograd: XX. vek.

Ballinger, Pamela. 2002. History in exile: memory and identity at the borders of the Balkans. Princeton: Princeton University Press.

(Bausinger, Hermann) Bauzinger, Herman. 2002. Etnologija. Beograd: Čigoja štampa.

Bestor, Theodore, C. „Veleprodaja sushija: Kultura i prodajni artikli na tokijskoj tržnici Tsukiji“, U: Promišljanje grada, Studije iz nove urbane antropologije, Setha M. Low (ur.), Zagreb: Jesenski i Turk, 25-177. 
Bertoša, Miroslav. 1972. Proština 1921. Pula: Glas Istre.

(Bielefeld, Urlich) Bilefeld, Urlih. 1998. Stranci: prijatelji ili neprijatelji. Zemun: Biblioteka XX vek; Beograd: Čigoja štampa.

Blagoni, Robert. 2006. Istra u zrcalu povijesnih smjeranja: identitet i strategije tumačenja odnosa čovjeka, jezika i svijeta. U Identitet Istre - ishodišta i perspective. Marino Manin i dr., (ur.) Zagreb: Institut društvenih znanosti Ivo Pilar, 464-483.

Blagonić, Sandi. 2007. Kad Hrvati marširaju. Zagreb: Naklada Jesenski i Turk.

Blagonić, Sandi. 2008. „Prilog etnohistoriji (sub)etničkiih skupina Vlaha i Bezaka u Istri“, Problemi sjevernog Jadrana, 8:101-131.

Bošković-Stulli, Maja. 2000. „Regionalne crte usmene hrvatske književnosti“, Narodna umjetnost, 37/2:151 - 162.

Bourdieu , Pierre. 1992. Što znači govoriti: ekonomija jezičnih razmjena. Naprijed: Zagreb.

Brouillard, Elisabet. „Postoji li belgijski nacionalni identjitet?“, U Europljani. Kultura i identitet, Daun, Åke; Janson, Sören (ur.). Zagreb: Naklada Jesenski i Turk, 257-272.

Buden, Boris. 1996. Barikade. Zagreb: Arkzin.

Bugarski, Ranko. 2002. Nova lica jezika: sociolingvističke teme. Beograd: Čigoja štampa.

(Connerton, Paul) Konerton, Pol. 2002. Kako društva pamte. Beograd: Samizdat

Custred, Glynn. 1997. „Language boundaries“. U Recent Studies in Contact Linguistic. Wolfgang Wölck, Annick de Houwer (ur.), Bonn: Dümler, 45-50.

Čapo Žmegač, Jasna. 1997. Hrvatski uskrsni običaji: korizmeno-uskrsni običaji hrvatskog puka u prooj polovici XX. stoljeća: svakidašnjica, pučka pobožnost, zajednica, Zagreb: Golden marketing.

Čolović, Ivan. 2000. Politika simbola: ogledi o političkoj antropologiji, Zemun: Biblioteka XX. vek; Beograd: Čigoja štampa.

Dežulović, Boris; Lucić, Predrag. 1998. Greatest shits: antologija suvremene hrvatske gluposti. Split: Feral Tribune.

Divković, Irena. 1995. „Uđe li Hrvatska u balkanski mrak, Istra će u Europu“, Slobodni tjednik, 23. lipnja 1995.

Erceg, Heni, Lucić, Predrag. 1995. „Histria \& Histerija“, Feral Tribune, 1. svibnja. 1995.

(Giordano, Christian) Đordano, Kristijan: Ogledi o interkulturnoj komunikaciji, Zemun: Biblioteka XX vek, Beograd: Čigoja štampa, 2001.

Harisson, Simon. 1995. „Four types of symbolic conflict“, Journal of the Anthropological Institute, 1:2/255-272.

Hobsbawm, Eric. 1983. „Introduction: Inventing tradition”. U The Invention of Tradition. Eric Hobsbawm i Ranger ur. Cambridge: Cambridge University Press, 1-14.

Hobsbawm, Eric J. 1993. Nacije i nacionalizam: program, mit, stvarnost. Zagreb: Novi liber.

Hudson, A. Richard. 1990. Sociolinguistic. Cambridge: Cambridge University Press.

Jakovčić, Ivan. 1995. „Dolaze novi dani i novi ljudi, gospodine Šeks“, Novi list, 25. listopada 1995.

Jambor, Davor. 1994. „Istra je svakom režimu bila neposlušna“, Arkzin, 5. kolovoza 1994.

Jardas, Ivo. 1971. Po grožnjanskom krasu: ljudi, običaji, folklor. Buje: Narodno sveučilište Buje.

(Jenkins, Richard) Dženkins, Ričard. 2001. Etnicitet u novom ključu: argumenti $i$ ispitivanja- Zemun: Biblioteka XX vek, Beograd: Čigoja štampa. 
Jović, Josip. 1993. „Ustima ka Italiji, 'auspuhom' prema Hrvatskoj“, Nedjeljna Dalmacija, 11. kolovoza 1993.

Kalapoš, Sanja. 2002. Rock po istrijanski: o popularnoj kulturi, regiji i identitetu, Zagreb: Naklada Jesenski i Turk.

Katunarić, Vjeran. 2003. Sporna zajednica: novije teorije o naciji i nacionalizmu. Zagreb: Jesenski i Turk, Hrvatsko sociološko društvo.

(Kertzer, I. David) Kercer, I. Dejvid. 2002. „Moć obreda”, U Politička antropologija: hrestomatija. Ċedomil Čupić ur. Beograd: Ċigoja štampa, 325-344.

Köstlin, Konrad. 2001. „Nova shvaćanja regije i culturekulture“. Narodna umjetnost 38/2: 3344.

Köstlin, Konrad. 2004. Austrifikacija Austrije: promicanje razlika. U Europljani. Kultura i identitet. Daun, Åke; Janson, Sören (ur.). Zagreb: Naklada Jesenski i Turk, 163-176.

Kuljiš, Denis. 2008. „Hrvatska u antici? To je nemoguće gđo Sanader“, Globus, 24. listopada 2008.

Latinović, Andrea. 1997. „Hrvatstvo se u Istri održalo stoljećima, pa mu ne treba zaštita Delbiancove stranke!“, Nedjeljna Dalmacija, 14. veljače 1997.

Lovrić, Mario. 1999. „Ne trebaju nas učiti hrvatstvu, to smo davno položili“, Obzor, 06. studenog 1999.

Lučić, Ivo. „Politička i medijska revizija prošlosti u Bosni i Hercegovini”. Status 11: 226-237.

Malenica, Anita. 1995. „IDS vode talijanaši!“, Slobodna Dalmacija, 11. rujna 1995.

Martin, Denis Constant. 1993. „Identiteti u politici”. Treći program hrvatskog radija, 41: 31-49.

Matetić Ronjgov, Ivan. 1925. „O istarskoj ljestvici”. Sv Cecilija 19/2: 37-42.

Merton, K. Robert. 1995, „The Thomas Theorem and The Matthew Effect", Social Forces, December 1995, 74(2): 379-424.

Meyer, Thomas. 2003. Mediokracija. Medijska kolonizacija politike. Zagreb: Fakultet političkih znanosti.

Orlić, Ivona. 2004. Franci Blašković i konstrukcija suvremenog istarskog identiteta. Magistarski rad, rukopis.

Orlić, Drago. 2005. „Četiri kamena u gastronomiji Istre“ U Alida Bremer (ur.) U mislima čupam borove. Istra u mislima, mašti i sjećanjima suvremenih stranih i domaćih pisaca. Zagreb: Vuković \& Runjić, 235-241.

Pauletta, Ivan Corrado. 2000. Histria kolaž 1999. / Histria Collage 1999. Pula: Mara Pula.

Prošić-Dvornić, Mirjana. „Modeli retradicionalizacije: put u budućnost kroz vraćanje u prošlost", Glasnik Etnografskog instituta SANU, 1995. (44) 293-309.

Rašeta, Boris. 1998. „Koza protiv cosa nostre“, Feral Tribune , 5. listopada 1998.

Rihtman-Auguštin, Dunja. 1992. „Etnologija socijalizma i poslije“. Etnološka tribina, 15: 81-89.

Rihtman-Auguštin, Dunja. 1988. Contributions to the Study of Contemporary Folklore in Croatia. Posebno izdanje 9. Zagreb: Zavod za istraživanje folklora, 9-21.

Rotta, Giuseppe. 1998. „S bizantskim mentalitetom Hrvatska se neće udaljiti od Balkana“, Novi list, 23. listopada 1998.

Senjković, Reana. 2002. Lica društva, likovi države. Zagreb: Institut za etnologiju i folkloristiku.

Slavec, Ingrid. 1988. „Marginalia to Ethnological Writing and Description.“ Etnološka stičišča. Ljubljana: Razprave Filozofske fakultete, 119-129. 
(Smith, Anthony D.) Smit, Antoni D. 1998. Nacionalni identitet, Zemun: Biblioteka XX vek; Beograd: Čigoja štampa.

Šetić, Nevio: 2003. Istarski razgovori ili Prilog viziji razvitka modernoga hrvatskoga društva u Istri, Zagreb: Profil.

Todorova, Maria. 1998. Imaginarni Balkan. Beograd: Čigoja štampa.

Tomčić, T. 1999. „HDZ-u mjesto na Blakanu“, Novi list, 23. prosinca 1999.

Towson, Michael. 1993. „Semantička bitka: zapadno-njemačke demokršćanske jezične strategije poslije 1973“. Treći program hrvatskog radija 41: 50-58.

U(rošević), M(irko). 2003. „Hoće li se rušiti ‘kažuni' na odmorištu Bale?“, Vjesnik, 16. veljače. 2003.

Valić, Tone. 1944. Štorice iz Proštine. Zagreb: Matica hrvatska.

Wehler, Hans-Ulrich. 2005. Nacionalizam: povijest, oblici, posljedice. Zagreb: Naklada Jesenski i Turk.

Žužić, Branka. 1997. „I nakon Nina, Nino!“, Slobodna Dalmacija, 10. lipnja.1997.

Sandi Blagonić

\title{
Istrian regere fines: Traditional Culture and the Balkans in Discursive Identity Construction
}

\begin{abstract}
Summary
The text offers an analysis of the discourse on traditional culture and Europe, or rather the Balkans, in the context of the regional political market. The interpretation of traditional culture of Istria corresponds to the political needs of the persons involved, so that it is used for this purpose to emphasise the identity-related specific feature of Istria as differing from the rest of Croatia. Within the regional discourse, Istria and the policy of the Istrian Democratic Party are interpreted as belonging to Europe and reflecting European values, while the nationalist discourse is presented as reflecting Balkanism.
\end{abstract}

Keywords: The Balkans; Istrian regionalism; Istrians, Europe; Istrian Democratic sabor; Croatian Democratic Union; traditional culture. 